Jeunesses de Shakespeare

\title{
Foreword
}

\section{Laetitia Sansonetti}

\section{(2) OpenEdition}

\section{Journals}

Electronic version

URL: http://journals.openedition.org/shakespeare/3792

DOI: $10.4000 /$ shakespeare.3792

ISSN: 2271-6424

\section{Publisher}

Société Française Shakespeare

\section{Electronic reference}

Laetitia Sansonetti, «Foreword », Actes des congrès de la Société française Shakespeare [Online], 34 | 2016, Online since 20 March 2016, connection on 23 September 2020. URL : http://

journals.openedition.org/shakespeare/3792; DOI : https://doi.org/10.4000/shakespeare.3792

This text was automatically generated on 23 September 2020

(c) SFS 


\title{
Foreword
}

\author{
Laetitia Sansonetti
}

\section{A "trust in youth" challenge}

1 In their rationale for "Young Shakespeare", the 2015 Conference of Société Française Shakespeare, Dominique Goy-Blanquet and François Laroque called Shakespeare's works "a 'trust in youth' challenge."

2 The speakers met the challenge with papers (gathered here in their revised versions) tackling various meanings of the relation between shakespeare and youth: the playwright's own young age when he wrote some of his plays, but also the age of his younger characters, for the two issues are often linked, as wells as the role a canonised (but not fossilised, far from it) Shakespearean corpus can play for today's youth which shows that Shakespeare remains forever young.

3 Several interconnected themes emerge. Youth is considered to be a period of learning, when character and cognitive faculties are not fully developed yet and need supervision from an adult to mature. Young characters are in a minority that can be a trigger for comedy (at their expense) or anxiety, but it can also lead them to rebel against the established order by making fun of the norms imposed by their elders. Likewise, young readers are often taken to lack the skills needed to understand Shakespeare's complex works and thus are sometimes offered versions that do not meet their expectations or cater to their needs. Recent counter-examples have shown that retelling the plays for a young audience can help reinvent the reception of those revered texts. The playwright's own youth when he composed some of his plays is equally ambiguous: seen in a teleological perspective that would look at the later plays as the crowning achievement of his dramatic art, "young Shakespeare" might still be an apprentice whose output lacks maturity... Taking into account the time needed for composition, which involves processes of collaboration and revision, but also the conception of time that features in the plays, allows to question interpretations of Shakespeare's "evolution" that would be simplistic. 
The relation of youth to maturity, between subordination and rebelliousness, opens up a path of enquiry to determine what makes youth, what defines its identity, with regard to the older generations that intend to serve as its role models - a point of view according to which Shakespeare will remain our elder. The codes inherited from the past do not have to feel like straightjackets out of which we might need to wriggle free, they can help build a fluid, independent identity, always redefining itself through appropriation and even misappropriation.

Those very codes can be intellectual or moral ones, but above all they refer to the live show that is drama, and as such are of an aesthetic nature. Faced with a difficult language, appropriations often resort to images, not as a substitution device but as a complementary medium, thus harking back to the experience of the stage itself, where bodies give texts a voice that allows them to live.

\section{Early plays?}

6 Sophie Chiari tackles a play which is quite difficult to date, since no copy of "Love's Labour's Won" has survived - and none may ever have existed. By suggesting we should consider Love's Labour's Lost to be the first half of an early diptych whose second half would be Much Ado about Nothing, Chiari invites us to rethink our ideas about the concept of series. It is no longer about events seen in their chronological order but according to a form of logical complementariness.

7 Lucy Munro offers a fascinating meticulous study of Pericles, showing that the play has been dated diversely at different times: it was first taken to be an early play, but has now joined the category of the late plays. Munro highlights what is at stake for the editing processes with such variations in dating, as far as collaboration is concerned, but also with regard to the character of Marina, depending on the text established by the respective editors. Munro's analysis thus reshuffles the opposition between early and late plays.

\section{Young characters}

8 Terri Bourus' essay brings together the debate around Hamlet's age and the controversies over the dating of the play itself in its various versions, thanks to a study of textual variants from one edition to the next combined with an empathetic approach to feelings associated with youth. That Hamlet might actually be a teenager worrying about a potential half-sibling born of his mother by his uncle, with whom he would have to share his inheritance, is a thought-provoking perspective.

9 Edel Lamb studies Shakespeare's Love's Labour's Lost and John Marston's What You Will, two plays in which young boys are staged in learning contexts. She analyses how gendered identities were shaped in Early Modern England but also, by focussing on the status of the period's young actors, she shows how the two plays highlight both the difficulties for boys to become adults and the talent necessary to play teenage roles.

Building upon anthropological studies of gift-giving, Anne-Kathrin Marquardt shows that the peculiar type of gift bestowed by Lear upon his daughters in King Lear triggers a generational conflict between parents and children. Her analysis allows to rethink the opposition between the elder daughters who were each given one half of the kingdom 
and both prove ungrateful, and the younger one, Cordelia, who was accused of being ungrateful and thus given nothing at all.

\section{Shakespeare for young people - Shakespeare, forever young}

How can "Shakespeare" speak to young people?

In order to find an answer to that question, Daniel Bender chooses a pragmatic - or, to use his own term, "pracademic" - approach to Love's Labour's Lost. To bridge the gap between Shakespeare's language and US students' everyday preoccupations, Bender suggests using situations that are likely to strike a chord with today's young people in order to design classroom activities aimed at developing skills that are as necessary today as they were in Shakespeare's time: speaking eloquently, managing one's money efficiently, and controlling one's sexuality.

Kate Harvey surveys the reception of Charles and Mary Lamb's Tales from Shakespeare, a book that brought "Shakespeare" to generations of children and was so popular that it seems to have conditioned the very genre of "Shakespeare for children" until a very recent date. She highlights the gendered distribution of roles between little boy readers and little girl readers that was planned by the authors, establishing an interesting parallel with Mary Lamb's own subordinate form of authorship.

The subject of Sarah Hatchuel and Ronan Ludot-Vlasak's article is the cult anime Candy Candy from the late 1970s, in which they study the complex references to Shakespeare's plays, but also to their most famous film adaptations. They show that those references, far from being merely decorative, actually build a proper ethics of performance. Just as Shakespeare's plays help Candy Candy's teenage characters become adults, they argue, so does the series help its own young audience grow up.

Pierre Kapitaniak's study of the webcomic Stick Figure Hamlet reveals another type of adaptation aimed not at a static "youth" but at an audience of young adults fully capable of appreciating the humour of its creator. Dan Carroll plays with visual codes close to children's drawings (with his stick figures), mixing them with codes from his own youth (figures from the Pac-Man video game). As Kapitaniak shows, from its financing strategies (through crowdfunding) to its broadcasting means (on the Internet), this work endorses a decisively "young" approach to adapting Shakespeare.

Marcia Williams has authored many comic books in which she retells shakespeare's plays, imagining them staged at the theatre in front of an audience of curious, fascinated (and sometimes naughty) spectators with whom her young readers can identify. With her typical passion (and sense of humour), she explains her outlook, referring to the Lambs, whose endeavour proved an incentive for her to provide young audiences with retellings of the plays that would first and foremost be good reads. 
AUTHOR

LAETITIA SANSONETTI

Université Paris Ouest Nanterre La Défense 